\title{
Modeling nitrogen loading in a small watershed in southwest China using a DNDC model with hydrological enhancements
}

\author{
J. Deng ${ }^{1}$, Z. Zhou ${ }^{1}$, B. Zhu ${ }^{2}$, X. Zheng ${ }^{1}$, C. Li ${ }^{3}$, X. Wang ${ }^{2}$, and Z. Jian ${ }^{2}$ \\ ${ }^{1}$ The State Key Laboratory of Atmospheric Boundary Layer Physics and Atmospheric Chemistry, Institute of \\ Atmospheric Physics, Chinese Academy of Sciences, Beijing 100029, China \\ ${ }^{2}$ Key Laboratory of Mountain Environment Evolvement and Regulation, Institute of Mountain Hazards and \\ Environment, Chinese Academy of Sciences, Chengdu, 610041, China \\ ${ }^{3}$ Complex Systems Research Center, Institute for the Study of Earth, Oceans and Space, University of \\ New Hampshire, 39 College Road, Durham, NH 03824, USA
}

Received: 21 May 2011 - Published in Biogeosciences Discuss.: 6 July 2011

Revised: 7 October 2011 - Accepted: 20 October 2011 - Published: 28 October 2011

\begin{abstract}
The degradation of water quality has been observed worldwide, and inputs of nitrogen $(\mathrm{N})$, along with other nutrients, play a key role in the process of contamination. The quantification of $\mathrm{N}$ loading from non-point sources at a watershed scale has long been a challenge. Processbased models have been developed to address this problem. Because $\mathrm{N}$ loading from non-point sources result from interactions between biogeochemical and hydrological processes, a model framework must include both types of processes if it is to be useful. This paper reports the results of a study in which we integrated two fundamental hydrologic features, the SCS (Soil Conservation Service) curve function and the MUSLE (Modified Universal Soil Loss), into a biogeochemical model, the DNDC. The SCS curve equation and the MUSLE are widely used in hydrological models for calculating surface runoff and soil erosion. Equipped with the new added hydrologic features, DNDC was substantially enhanced with the new capacity of simulating both vertical and horizontal movements of water and $\mathrm{N}$ at a watershed scale. A long-term experimental watershed in Southwest China was selected to test the new version of the DNDC. The target watershed's 35.1 ha of territory encompass 19.3 ha of croplands, 11.0 ha of forest lands, 1.1 ha of grassplots, and 3.7 ha of residential areas. An input database containing topographic data, meteorological conditions, soil properties, vegetation information, and management applications was established and linked to the enhanced DNDC. Driven by the input database, the DNDC simulated the surface runoff flow, the subsurface leaching flow, the soil erosion, and the $\mathrm{N}$ loadings from the target watershed. The modeled water
\end{abstract}

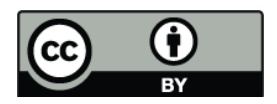

Correspondence to: $\mathrm{B}$. Zhu

(bzhu@imde.ac.cn) flow, sediment yield, and $\mathrm{N}$ loading from the entire watershed were compared with observations from the watershed and yielded encouraging results. The sources of $\mathrm{N}$ loading were identified by using the results of the model. In 2008, the modeled runoff-induced loss of total $\mathrm{N}$ from the watershed was $904 \mathrm{~kg} \mathrm{~N} \mathrm{yr}^{-1}$, of which approximately $67 \%$ came from the croplands. The enhanced DNDC model also estimated the watershed-scale $\mathrm{N}$ losses $\left(1391 \mathrm{~kg} \mathrm{Nyr}^{-1}\right)$ from the emissions of the $\mathrm{N}$-containing gases (ammonia, nitrous oxide, nitric oxide, and dinitrogen). Ammonia volatilization $\left(1299 \mathrm{~kg} \mathrm{~N} \mathrm{yr}^{-1}\right)$ dominated the gaseous $\mathrm{N}$ losses. The study indicated that process-based biogeochemical models such as the DNDC could contribute more effectively to watershed N loading studies if the hydrological components of the models were appropriately enhanced.

\section{Introduction}

In modern agriculture, intensive fertilizer applications are used to maintain optimum yields. However, the high application rates of nitrogenous fertilizer and the low efficiency associated with its use mean that superfluous nitrogen $(\mathrm{N})$ remains in the soil. This excess nitrogen could eventually move from the soil into the atmosphere or into water bodies. This source of nitrogen loading has produced a series of environmental problems at the local, regional or global scales (e.g., Carpenter et al., 1998; Cassman et al., 2002; Galloway et al., 2003; Moffat, 1998; Vitousek et al., 1997). Increases in $\mathrm{N}$ loading originating from agricultural lands have been observed worldwide (e.g., Haycock et al., 1993; Rabalais et al., 1996; Z. Zhu et al., 2006). The excessive $\mathrm{N}$ imported into aquatic ecosystems has increased the risks of human cancer,

Published by Copernicus Publications on behalf of the European Geosciences Union. 
water body hypoxia, and biodiversity loss (e.g., Rabalais, 2002; Seitzinger, 2008; World Health Organization, 2004). Furthermore, the emissions of nitrous oxide $\left(\mathrm{N}_{2} \mathrm{O}\right)$, nitric oxide (NO), and ammonia $\left(\mathrm{NH}_{3}\right)$ from terrestrial ecosystems contribute to global warming, acid rain, and other sources of deterioration of the atmospheric environment (e.g., IPCC, 2007; Vitousek et al., 1997).

Quantifying the impacts of alternative management practices on the $\mathrm{N}$ losses from terrestrial ecosystems is essential for mitigating the $\mathrm{N}$ loading. Many studies have been conducted to investigate $\mathrm{N}$ losses at different spatial scales by making relevant measurements (e.g., Jaynes et al., 2001; Jordan et al., 1997a, b; Kramer et al., 2006; Schlesinger et al., 1999). However, measurement approaches are often limited by their spatial or temporal coverage. The heterogeneity of $\mathrm{N}$ activity in the soil means that extrapolation of the measured results to large regions or over extended time periods is an enduring challenge. Modeling approaches have been developed to address this limitation. In general, two kinds of modeling approaches have been used to predict nutrient loadings. On one hand, a number of hydrology-oriented models, such as MIKE SHE (Refsgaard and Storm, 1995), RHESSys (Band et al., 2001; Tague and Band, 2004), SWAT (Arnold et al., 1998; Neitsch et al., 2001; Saleh et al., 2000), and HSPF (Bicknell et al., 1997), have been enhanced to predict nutrient loadings by including nutrient transport and transformation into the framework of a hydrology-based model. On the other hand, several biogeochemistry-oriented models that portray the carbon (C) and $\mathrm{N}$ cycles have been enhanced by including more accurate hydrologic features (e.g., Johnsson et al., 1987; Li et al., 2006; Zhang et al., 2002). The two approaches, hydrology- and biogeochemistry-based models, have contrasting advantages and disadvantages. The spatially distributed hydrologic models incorporate hydrologic algorithms for simulating water movement. When applied at a watershed scale, they are usually equipped with a spatially distributed input database to reflect the spatial heterogeneity of the environmental variables that drive water movement. However, the hydrology-oriented models are usually relatively weak in describing biogeochemical processes such as $\mathrm{C}$ and $\mathrm{N}$ transformations, which are crucial for simulating the losses of soil N (e.g., Band et al., 2001; Boyer et al., 2006; Hu et al., 2007; Li et al., 2006; Yuan et al., 2003). In contrast, the representations of $C$ and $N$ processes in biogeochemistry-based models are relatively detailed, but these models are unable to account for the transport of nutrients through lateral flow (e.g., Li et al., 2006; Tonitto et al., 2010). Because $\mathrm{N}$ loading from watersheds are jointly controlled by water flow and $\mathrm{N}$ transformation (e.g., Band et al., 2001; Kimura et al., 2009), integration of the hydrologic and biogeochemical processes into a single framework is vitally important for modeling $\mathrm{N}$ loading. A process-based biogeochemistry model, the Denitrification-Decomposition, or DNDC, model, was recently enhanced by incorporating two fundamental hydrologic features, the SCS (Soil Conservation
Service) curve function for quantifying surface runoff and the MUSLE (Modified Universal Soil Loss Equation) for quantifying soil erosion (Deng et al., 2011). These two new features have enabled DNDC to simulate water and nutrient movements in both the horizontal and the vertical dimension (Deng et al., 2011). The innovation has provided a new opportunity for DNDC to be applied for modeling N loading at a watershed scale. This paper discusses our use of the enhanced DNDC to quantify N loading from a small watershed dominated by agro-ecosystems in Southwest China.

\section{Watershed description}

A small watershed (N $31^{\circ} 16^{\prime}, \mathrm{E} 105^{\circ} 28^{\prime}, 400$ to $600 \mathrm{~m}$ a.s.l.; hereafter termed the Yanting watershed) in Yanting county in Sichuan province, China was selected to test the new hydrology-enhanced DNDC. The Yanting watershed is located along the upstream reaches of the Yangtze River, the longest river in China. Eutrophication is widespread in the Yangtze (e.g., Wang et al., 2006; B. Zhu et al., 2006, 2009). The watershed possesses a well-defined boundary and is located within a mountainous area. An agroecological experimental station, a component of the Chinese Ecological Research Network (CERN), was established in the watershed in 1980. Measurements of meteorology, hydrology, vegetation, soil properties, sediment and nutrient loadings, and emissions of $\mathrm{N}$ gases have been continuously conducted at this station. The resulting datasets have furnished a sound basis for testing the enhanced model at a watershed scale.

The Yanting watershed (total area 35.1 ha) is dominated by croplands (19.3 ha, of which $78 \%$ was used for upland crops and $22 \%$ for paddy rice during the study period). The rest of the watershed consists of 11.0 ha of forest lands, 3.7 ha of residential areas, and 1.1 ha of grassplots (Fig. 1). During the study period, the major crops in the watershed were maize (Zea mays L.), winter wheat (Triticum aestivum L.), cole (Brassica napus L.), and paddy rice (Oryza sativa). The summer maize-winter wheat rotation, summer rice-winter cole rotation, and paddy rice were adopted in the dry land, seasonal paddy, and paddy field, respectively, under the local conventional management. The crop fields were intensively managed and the application rates of nitrogenous fertilizer were as high as $130-330 \mathrm{~kg} \mathrm{Nha}^{-1}$ per year. The major fertilizer types were ammonium bicarbonate and urea. Neither the forest lands nor the grassplots received any fertilizer. The animal and human wastes produced in the residential areas were initially stored in the local digesters and subsequently applied to the croplands as manure fertilizer. During periods of rainfall, the stored manure could be leached by the runoff and could then flow directly into the drainage system in the watershed. The dominant soil in the watershed is classified as Pup-Orthic Entisol in the Chinese Soil Taxonomy or Entisol in the US Soil Taxonomy and is distributed along the hill slopes (B. Zhu et al., 2009). Because of its purple color, the 


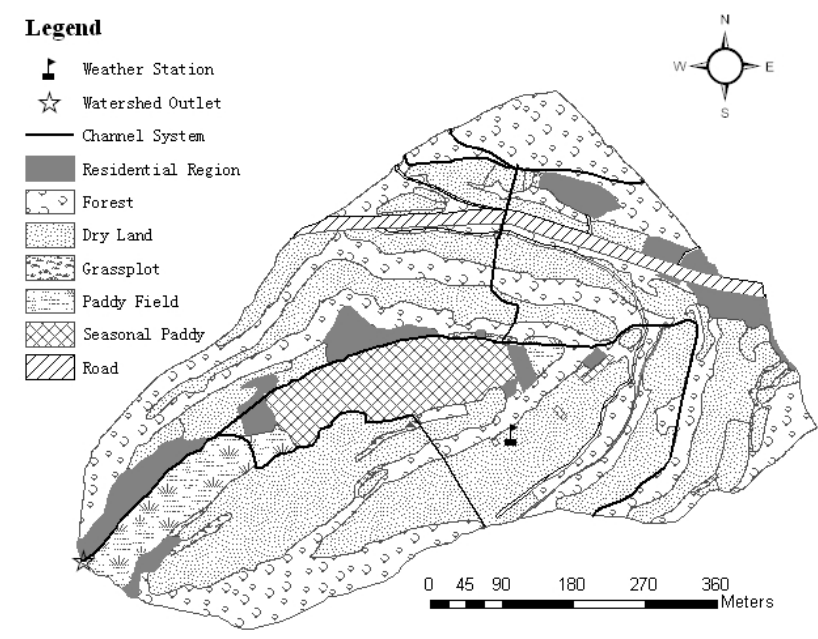

Fig. 1. Land use, channel system, and monitoring locations in the Yanting watershed.

soil is locally called purple soil. Rice paddies dominate the low-lying areas of the watershed. The paddy soil is classified as Stagnic Anthrosols in the Chinese Soil Taxonomy or Anthrosols in the US Soil Taxonomy (Gong, 1999).

The Yanting watershed exhibits a typical subtropical monsoon climate. During the period 1981-2006, the annual mean temperature was $17.3^{\circ} \mathrm{C}$, and the precipitation was $826 \mathrm{~mm}$. According to the meteorological data for the area, 5.9\%, $65.5 \%, 19.7 \%$ and $8.9 \%$ of the annual precipitation occurred in spring, summer, autumn and winter, respectively (B. Zhu et al., 2009). Lysimeters with various slopes are permanently installed in the fields to measure surface runoff and subsurface drainage flow. During the rainy period, surface runoff and subsurface drainage flows are collected by the drainage network and then discharged from the watershed outlet (Fig. 1). The natural and manmade channels in the Yanting watershed form a drainage system that produces steady water flows during the rainy season (Fig. 1). During the period 2007-2008, the amount of water flow and the concentrations of sediment, particulate $\mathrm{N}$, nitrate and total $\mathrm{N}$ (including particulate and dissolved forms of $\mathrm{N}$ ) were measured at the outlet of the watershed. The monthly watershed fluxes of water flow, sediment, and $\mathrm{N}$ loading were calculated based on the data measured at the watershed outlet.

\section{Modification of the DNDC}

The DNDC is a process-based model originally developed for quantifying $\mathrm{C}$ sequestration and greenhouse gas emissions from terrestrial ecosystems. The DNDC family consists of three related models: DNDC for agroecosystems ( $\mathrm{Li}, 2000$; $\mathrm{Li}$ et al., 1992a, b), Forest-DNDC for forest ecosystems ( $\mathrm{Li}$ et al., 2000; Stange et al., 2000) and Manure-DNDC for livestock operations systems. A relatively complete suite of biochemical and geochemical processes (e.g., plant uptake, decomposition, nitrification, denitrification, ammonia volatilization, fermentation) have been embedded in the model. These capabilities enable the model to correctly compute the complex transformations of $\mathrm{C}$ and $\mathrm{N}$ in terrestrial ecosystems. Traditionally, the DNDC only calculated the vertical water movement driven by precipitation, transpiration, evaporation, infiltration, and drainage at a site or a field scale (e.g., Li et al., 2006; Tonitto et al., 2007, 2010; Zhang et al., 2002). The model did not explicitly simulate surface runoff and was therefore unable to estimate the transport of sediment or nutrients in the horizontal dimension. This limitation prevented the model from simulating the movements of water, $\mathrm{C}$, and $\mathrm{N}$ at a watershed scale. To correct this deficiency, a novel modification was made to allow the DNDC to calculate the horizontal movements of water and nutrients by incorporating the SCS curve and MUSLE functions in the model framework in a pilot study (Deng et al., 2011). The SCS curve is a widelyused method for calculating surface runoff based on precipitation and on soil hydraulic parameters such as curve number $(\mathrm{CN})$, slope, and initial water abstraction (the value that must be exceeded by accumulated precipitation before surface runoff can occur) (Mockus, 1972; Williams, 1995). The MUSLE functions calculate soil erosion based on the surface runoff and other soil properties, including factors of soil erodibility, surface cover, management, topography, and the soil coarse fragment (Williams, 1975, 1995; Wischmeier and Smith, 1978). The two fundamental hydrologic features of surface runoff and soil erosion have been incorporated in the DNDC at the code level so that the biogeochemical and hydrologic processes can exchange data at each daily time step. The details of the model modification and the results of the preliminary tests of the model using the field-scale observations for the Yanting watershed have been reported by Deng et al. (2011). This paper reports the results of our further tests of the enhanced DNDC at a watershed scale.

In this study, the enhanced DNDC was used to estimate the $\mathrm{N}$ losses across the watershed, including croplands, grassplots, and forest lands. New interfaces were also constructed to allow the modeling framework to address the different ecosystems in the watershed.

\section{Database construction}

To implement the simulations with the DNDC for the target watershed, we established a database that would contain all the input information required by the enhanced DNDC. The basic unit chosen for the modeling database was the hydrologic response unit (HRU), which is frequently chosen for use with a suite of hydrologic models (e.g., Leavesley et al., 2002; Neitsch et al., 2001). An HRU is defined as a land area possessing uniform land cover, soil properties, and management practices. The HRUs for a given watershed can be 
represented by using geographic information system (GIS) tools to integrate topography, land-use types, and soil properties (e.g., Leavesley et al., 2002; Neitsch et al., 2001).

The channel system, or drainage network, plays a key role in aggregating the flows of water and nutrients at the watershed scale. The drainage network in the Yanting watershed was represented based on the gridded digital elevation model (DEM) by referring topographic and hydrological knowledge (Jenson and Domingue, 1988; Martz and Garbrecht, 1993; Turcotte et al., 2001). In this study, the GIS software ArcGIS (ESRI, USA) was used to convert the DEM data for the Yanting watershed into the topographic parameters required, such as surface slope, slope length, and channel length. The watershed delineation and discretization were performed by (1) preprocessing the DEM data using the sink filling technique; (2) calculating the water flow direction and the amount of accumulated water based on the steepest gradient for each grid cell; (3) fixing the threshold value of the drainage area by comparing the actual drainage network with the delineated drainage network; (4) delineating the channel system; (5) determining the catchment outlet and the interactions of linked channels; and (6) partitioning the whole watershed into subwatersheds based on the channel system. The procedure was designed according to methods for watershed delineation and discretization described in relevant publications (e.g., Maidment, 2002; Martz and Garbrecht, 1993; Whiteaker et al., 2003). The main characteristics of the study watershed, including the watershed boundary, the channel network, the subwatersheds, and the spatial configuration of each subwatershed, were fixed subsequent to the discretization of the watershed. We assumed that the water, sediment, and $\mathrm{N}$ released from the land phase were transported along the channel network and routed directly into the watershed outlet.

Based on the local DEM with a resolution of $5 \mathrm{~m} \times 5 \mathrm{~m}$, we fixed the threshold value of the drainage area by referring to the actual drainage network. The Yanting watershed was partitioned into 13 subcatchments, hydrologically connected through the channel system. In combination with the land-cover and soil types, 166 HRUs were determined within the entire watershed. The HRU system was used to organize all the input information into a geospatial database. In the database, topographic parameters (e.g., surface slope, slope length, channel length, and HRU area) were determined based on the local DEM by using ArcGIS for spatial analysis. The crop fields were generalized into three categories (i.e., summer maize-winter wheat rotation, summer rice-winter cole rotation, and paddy rice). The forested lands were dominated with cypress (Cypressus funebris) based on field survey. The required meteorological data (e.g., daily temperature, precipitation, and maximum $0.5 \mathrm{~h}$ rainfall) were obtained from the meteorological station located within the watershed. Soil data (e.g., bulk density, soil organic $\mathrm{C}$ content, $\mathrm{pH}$, clay fraction, field capacity, and wilt point) were measured in situ. The plant phenology and the physiological input parameters for the crops, grass or forest were obtained from local observations. Detailed information on management practices was obtained from a field survey. This information included crop type, planting/harvest dates, tillage, fertilization, irrigation/flooding, manure amendment, and residue management for croplands or grassplots; and forest type and forest age for forested lands. To support the simulations related to the SCS curve and MUSLE functions, we empirically estimated several hydrological parameters, including the initial $\mathrm{CN}$ value, the soil erodibility factor $(\mathrm{K})$, the soil surface cover and management factor $(\mathrm{C})$, and the soil conservation management factor $(\mathrm{P})$ in a preliminary study focusing on upland crop fields within the same watershed (Deng et al., 2011). In this study, the value of the soil erodibility factor $(\mathrm{K})$ for the watershed was set at 0.4 , the same value used for the uplands, based on the homogeneity of soil properties across the watershed. The soil conservation management factor $(\mathrm{P})$ for the forest lands and the grassplots was set as 1.0 because no specific soil conservation management practices (e.g., contour tillage, contour strip-cropping or terrace land-reforming) were used in these areas. The value of $\mathrm{P}$ for the rice paddy fields was set at 0.01 , the same value reported by previous studies (Cai et al., 2000; Hua et al., 2007). Calibration against the observations made at the watershed outlet during 2007 was used to fix the respective values of the initial curve number $(\mathrm{CN})$ and the soil surface cover and management factor (C) at 77 and 0.18 for paddies, 70 and 0.01 for forest lands, and 77 and 0.06 for grassplots. The major input parameters are summarized in Table 1. All of the above-listed input parameters were used in the hydrology-enhanced DNDC to quantify the $\mathrm{N}$ loading from the various ecosystems in the Yanting watershed. The modeled runoff, sediment yield, and $\mathrm{N}$ loading from the Yanting watershed were compared with the field data measured during 2008.

\section{Model tests}

The DNDC was run at the HRU level across the entire watershed. For each HRU, the DNDC simulated plant growth, soil climate, surface runoff, subsurface leaching flow, sediment yield from soil erosion, and soil $\mathrm{N}$ dynamics using a daily or hourly time step. When surface runoff or subsurface drainage flow occurred, a fraction of the soil $\mathrm{N}$ was released from the soil into the runoff flow. The soil $\mathrm{N}$ lost with the runoff flow included the particulate $\mathrm{N}$ (e.g., adsorbed ammonium or organic $\mathrm{N}$ ) and the dissolved $\mathrm{N}$ (e.g., nitrate or ammonium). The sediment yield, particulate $\mathrm{N}$ loss, and dissolved $\mathrm{N}$ loss from the residential areas were estimated to be $4.3 \mathrm{tha}^{-1} \mathrm{yr}^{-1}, 14 \mathrm{~kg} \mathrm{Nha}^{-1} \mathrm{yr}^{-1}$, and $33 \mathrm{~kg} \mathrm{Nha}^{-1} \mathrm{yr}^{-1}$, respectively, based on a previous study by Luo et al. (2008). During the transport of the sediment and $\mathrm{N}$ in the channels, we assumed that the sediment and $\mathrm{N}$ discharged into the channel system were reduced during transport by $10 \%$ and 
Table 1. Primary input variables.

\begin{tabular}{l|l}
\hline Items & Input $^{\text {a }}$ \\
\hline Topographic data & $\begin{array}{l}\text { Longitude, latitude, altitude, area, slope length, slope, } \\
\text { channel length, channel slope. } \\
\text { Meteorological condition } \\
\text { Air temperature, precipitation, maximum half hour rainfall, wet nitrogen (N) } \\
\text { deposition, wind speed. } \\
\text { Soil texture, depth, bulk density, pH, soil organic carbon content, } \\
\text { initial soil N content,saturated hydrologic conductivity, } \\
\text { porosity, field capacity, wilt point, soil erodibility factor, soil coarse fragment factor. } \\
\text { Vegetation type, optimal yield, biomass fraction, plant N content, water } \\
\text { Vegetation information } \\
\text { Management applications } \\
\text { Crop rotation, planting date, harvest date, fertilization, } \\
\text { manure amendment, irrigation, flooding, drainage, tillage, grazing, } \\
\text { weeding, tree chopping, surface cover and management factor, soil conservation practices. }\end{array}$ \\
\hline
\end{tabular}

a Details can be found in the manuals for the DNDC and the PnET-N-DNDC (http://www.dndc.sr.unh.edu/?page_id=4).

$30 \%$, respectively, owing to the sedimentation or $\mathrm{N}$ transformation occurring in the channel system, based on the findings of Luo et al. (2009). The watershed-scale runoff (the sum of surface runoff and subsurface drainage flow), sediment, and $\mathrm{N}$ loading fluxes on a monthly or annual basis for 2008 were calculated by summing the daily fluxes modeled for all of the HRUs.

The watershed-scale modeling results for 2008 were compared with the corresponding observations on a monthly and on an annual basis. Two statistical indexes, the coefficient of determination $\left(R^{2}\right)$ and the Nash-Sutcliffe index of model efficiency (ME), were utilized to make quantitative comparisons between the modeled and measured results. The $R^{2}$ value examines the correlation between model predictions and field measurements (Eq. 1). The ME is a measure of the improvement in the predictions relative to the mean of the measurements (Eq. 2). A positive value of ME indicates that the model predictions are better than the mean of the measurements, and the best model performance has ME value equal to 1 (Miehle et al., 2006; Nash and Sutcliffe, 1970).

$$
\begin{aligned}
R^{2} & =\left(\frac{\sum_{\mathrm{i}=1}^{n}\left(o_{\mathrm{i}}-\bar{o}\right)\left(p_{\mathrm{i}}-\bar{p}\right)}{\sqrt{\sum_{\mathrm{i}=1}^{n}\left(o_{\mathrm{i}}-\bar{o}\right)^{2} \sum_{\mathrm{i}=1}^{n}\left(p_{\mathrm{i}}-\bar{p}\right)^{2}}}\right)^{2} \\
\mathrm{ME} & =1-\frac{\sum_{\mathrm{i}=1}^{n}\left(p_{\mathrm{i}}-o_{\mathrm{i}}\right)^{2}}{\sum_{\mathrm{i}=1}^{n}\left(o_{\mathrm{i}}-\bar{o}\right)^{2}}
\end{aligned}
$$

where $o_{\mathrm{i}}$ and $p_{\mathrm{i}}$ are the measured and simulated values, $\bar{o}$ and $\bar{p}$ are their means and $\mathrm{n}$ is the number of values.

\subsection{The temporal patterns of runoff, sediment, and $\mathrm{N}$ loading fluxes}

The patterns and magnitudes of modeled monthly runoff (the sum of surface runoff and subsurface drainage flow) and sediment loading are consistent with the data gathered at the outlet of the Yanting watershed during 2008 (Fig. 3b and c). The modeled monthly runoff fluxes varied between 0 to $47552 \mathrm{~m}^{3}$ month $^{-1}$ with a mean of $10746 \mathrm{~m}^{3}$ month $^{-1}$. The results are comparable to the observed monthly runoffs, which varied between 0 to $41101 \mathrm{~m}^{3}$ month $^{-1}$ with a mean of $10462 \mathrm{~m}^{3}$ month $^{-1}$. The modeled sediment fluxes varied between 0 to $32 \mathrm{t} \mathrm{month}^{-1}$ with a mean of $9.5 \mathrm{t} \mathrm{month}^{-1}$. These results are in agreement with the measured sediment fluxes, which ranged from 0 to $31 \mathrm{tmonth}^{-1}$ with a mean of $10 \mathrm{tmonth}^{-1}$. The correlations between the simulated and measured monthly results are statistically significant (ME $=0.95, R^{2}=0.96, p<0.01$ for runoff, and $\mathrm{ME}=0.95$, $R^{2}=0.96, p<0.01$ for sediment fluxes). The satisfactory performance of the DNDC for runoff or sediment yield should provide a sound basis for further modeling of $\mathrm{N}$ losses produced by the runoff flow or by eroded sediment.

The DNDC calculates the soil $\mathrm{N}$ losses for particulate and dissolved forms of $\mathrm{N}$. The particulate $\mathrm{N}$ loss is quantified based on the organic and inorganic $\mathrm{N}$ contents in the eroded soil, and the dissolved $\mathrm{N}$ loss is quantified by simulating the runoff flow and the distribution of $\mathrm{N}$ between the liquid and solid phases in the soil profile (Deng et al., 2011; Li et al., 2006). For 2008, the modeled monthly total $\mathrm{N}$ loadings varied between 0 to $259 \mathrm{~kg} \mathrm{~N}$ month $^{-1}$, with a mean of $52 \mathrm{~kg} \mathrm{~N}$ month $^{-1}$. The observed monthly total $\mathrm{N}$ loadings varied between 0 to $216 \mathrm{~kg} \mathrm{~N}$ month $^{-1}$, with a mean of $55 \mathrm{~kg} \mathrm{~N}$ month $^{-1}$. The modeled and measured results show substantial agreement. The means of the modeled monthly particulate $\mathrm{N}$ and nitrate loading rates were 8.5 and $31.9 \mathrm{~kg} \mathrm{~N}$ month $^{-1}$, respectively. These results are comparable to the observations, whose means were 9.8 and $31.5 \mathrm{~kg} \mathrm{~N}$ month $^{-1}$ for particulate $\mathrm{N}$ and nitrate loading rates, respectively. Both the measured and modeled data indicate that dissolved nitrate loading accounted for approximately $60 \%$ of the total $\mathrm{N}$ loading from the Yanting watershed. The comparisons showed significant correlations $(p<0.01)$ 


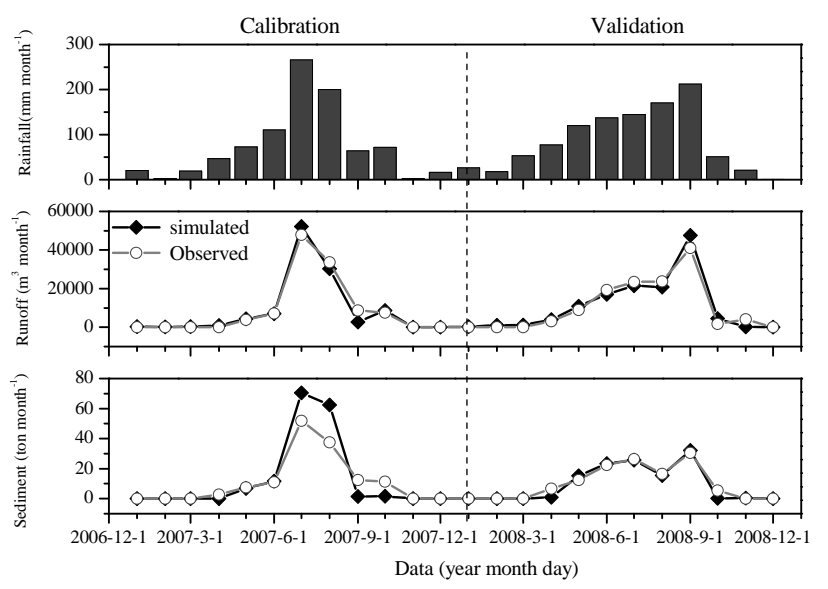

Fig. 2. Monthly precipitation (a), simulated and measured runoff (the sum of surface runoff and subsurface drainage flow) (b), and sediment yields (c) for the calibration (2007) and validation (2008) years.

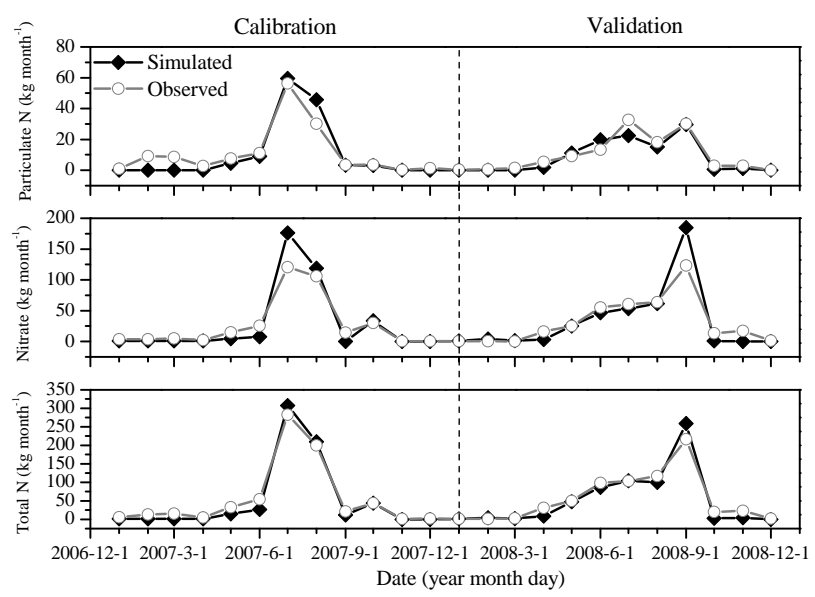

Fig. 3. Simulated and measured monthly particulate nitrogen loadings (a), nitrate loadings (b) and total nitrogen loadings (c) for the calibration (2007) and validation (2008) years.

between the measured and modeled particulate $\mathrm{N}$ loadings $\left(R^{2}=0.89\right.$ and $\left.\mathrm{ME}=0.87\right)$, nitrate loadings $\left(R^{2}=0.92\right.$ and $\mathrm{ME}=0.70)$, and total $\mathrm{N}$ loadings $\left(R^{2}=0.97\right.$ and $\left.\mathrm{ME}=0.93\right)$. These results indicate that the magnitudes and patterns of the modeled monthly $\mathrm{N}$ loading rates agree with the observations (Fig. 4).

The modeled data demonstrate that $\mathrm{N}$ loading from the watershed varied seasonally. In the spring, autumn, and winter of 2008, the low $\mathrm{N}$ loading rates were associated with the low precipitation that occurred during those seasons (Figs. 3a and 4). The DNDC simulated the accumulation of inorganic $\mathrm{N}$ in the soil profile during the spring, autumn, and winter resulting from fertilization. When high precipitation occurred during the summer, the accumulated $\mathrm{N}$ was allocated by the

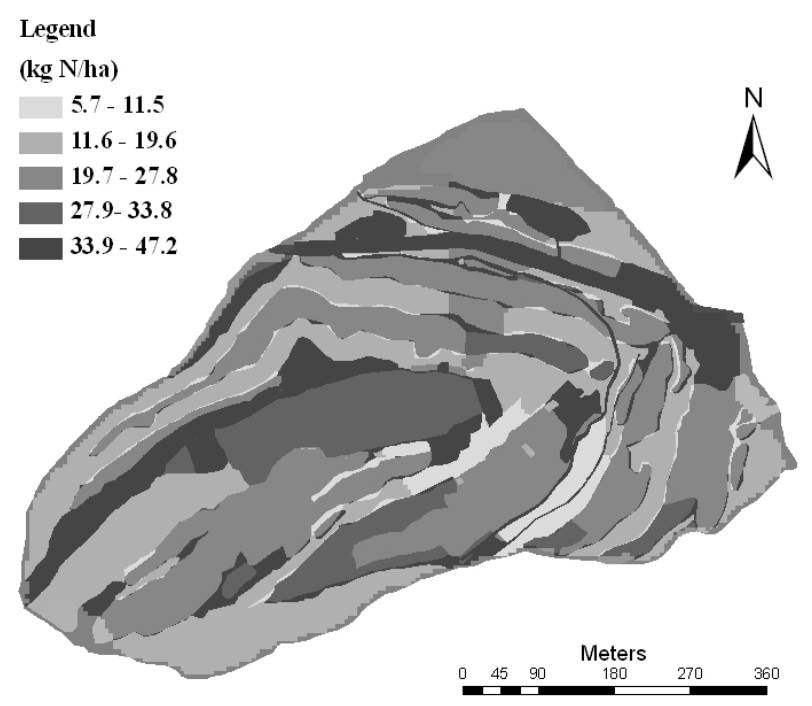

Fig. 4. The spatial distribution of the annual total $\mathrm{N}$ loss rate in the Yanting watershed. The $\mathrm{N}$ loss rate for the residential regions was based on local observations.

model to the surface runoff or the subsurface drainage flow. This discharge of $\mathrm{N}$ produced high $\mathrm{N}$ loading rates from June through September. This seasonal pattern of $\mathrm{N}$ loading was also observed by other investigators in the Yanting watershed (Wang et al., 2006; B. Zhu et al., 2009). However, discrepancies still remained between the modeled results and the observations. For example, the modeled $\mathrm{N}$ loading rates were a little higher than the corresponding observed values during the rainy season (e.g., September 2008) (Fig. 4). This overestimation could be the result of the model's simplification of in-channel biogeochemical processes such as aquatic plant uptake or denitrification.

\subsection{The sources of $\mathrm{N}$ loading}

Identifying the sources of $\mathrm{N}$ loading is critical for mitigating $\mathrm{N}$ contamination. By linking the DNDC to the database containing the spatially differentiated information on land use, topography, soil, and management practices, we were able to calculate the spatial distribution of the total runoffinduced $\mathrm{N}$ loss across the entire watershed (Fig. 5). Our results indicated that the total $\mathrm{N}$ loss rates during 2008 varied from 5.7 to $47.2 \mathrm{~kg} \mathrm{Nha}^{-1} \mathrm{yr}^{-1}$ across the HRUs in the watershed (Fig. 5). The spatial distribution of the modeled total $\mathrm{N}$ loss rates was correlated with the types of land use in the watershed. This result is consistent with the findings of previous studies (e.g., Jordan et al., 1997b; Smith et al., 1997). The modeled results indicated that the major source of $\mathrm{N}$ loading was the fertilized crop fields, which accounted for $67 \%$ of the watershed $\mathrm{N}$ loading (Table 2). The $\mathrm{N}$ released from the residential areas, which was estimated based on field measurement, accounted for $19 \%$ of the total 


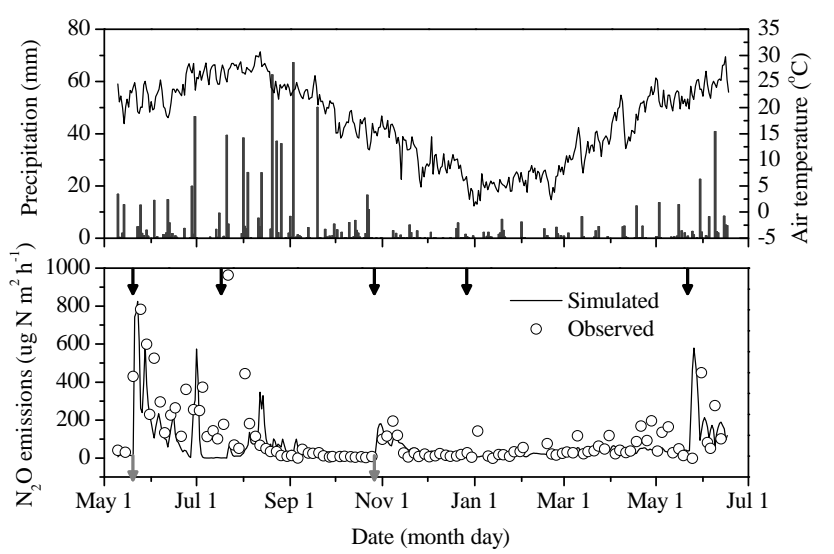

Fig. 5. Precipitation and air temperature (a), simulated and observed nitrous oxide emissions (b) from typical cropland planted with maize and winter wheat in the Yanting watershed during the rotational year of 2004-2005. The gray and black arrows indicate the dates of tillage and fertilization, respectively.

$\mathrm{N}$ loading (Table 2). The model's results are consistent with the findings of local field investigations (B. Zhu et al., 2006).

\subsection{Nitrogenous gas emissions}

As important components of terrestrial $\mathrm{N}$ cycling, emissions of nitrogenous gases result in removal of $\mathrm{N}$ from the plantsoil systems. This process inherently affects the loading of soil $\mathrm{N}$ to the water systems. During the simulations, the DNDC automatically calculated daily fluxes of ammonia $\left(\mathrm{NH}_{3}\right)$, nitrous oxide $\left(\mathrm{N}_{2} \mathrm{O}\right)$, nitric oxide $(\mathrm{NO})$, and dinitrogen $\left(\mathrm{N}_{2}\right)$. The performance of the DNDC for modeling $\mathrm{N}$ gas emissions has been widely reported and has also been tested for the Yanting watershed (Wang et al., 2009). Figures 5 and 6 show the measured and modeled daily $\mathrm{N}_{2} \mathrm{O}$ emissions from both the cropland and forest land within the Yanting watershed.

The modeled annual $\mathrm{NH}_{3}, \mathrm{~N}_{2} \mathrm{O}, \mathrm{NO}$, and $\mathrm{N}_{2}$ emissions from the Yanting watershed (excluding the residential areas) were $1299,34.1,5.6$, and $51.9 \mathrm{~kg} \mathrm{~N}$, respectively, for 2008 (Table 2). The $\mathrm{NH}_{3}$ emission from croplands dominated the losses of gaseous forms of $\mathrm{N}$. The high rate of nitrogenous fertilizer application in croplands evidently produced the high emission levels of $\mathrm{N}$ gases. However, because the available data are not sufficient for validating the modeled emissions of $\mathrm{N}$ gases for the target watershed, the modeled results remain large uncertain.

\section{Discussion}

The $\mathrm{N}$ loading from agricultural non-point sources threaten water quality worldwide (e.g., Gile, 2005; Rabalais, 2002; Seitzinger et al., 2005). There is an urgent need to quantify and mitigate $\mathrm{N}$ loading at a watershed scale. The interaction between $\mathrm{N}$ biogeochemical and hydrological processes

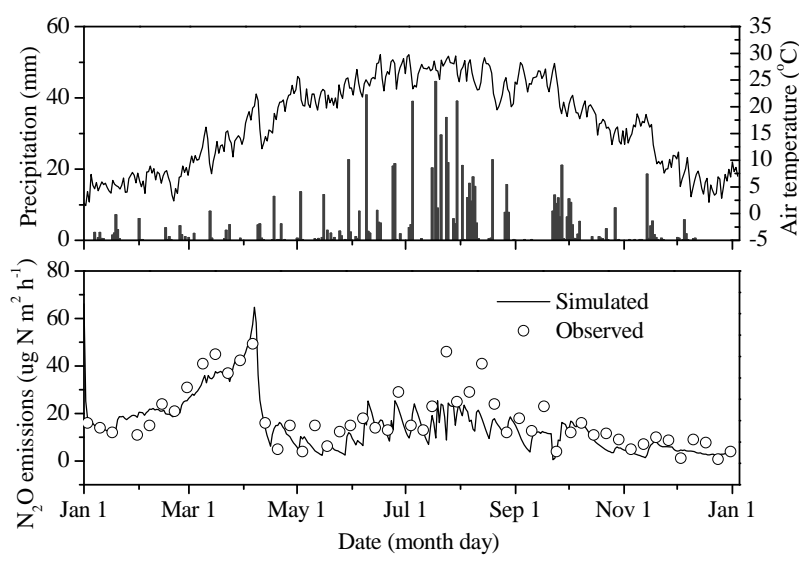

Fig. 6. Precipitation and air temperature (a), simulated and observed nitrous oxide emissions (b) from typical forestland in the Yanting watershed during 2005. Modified from Wang et al., 2009.

is intrinsic to and plays a key role in $\mathrm{N}$ loading. This interaction should therefore receive emphasis in connection with the estimation and mitigation of $\mathrm{N}$ loading (e.g., Cirmo and McDonnell, 1997; Kimura et al., 2009; Li et al., 2006). Because of the detailed biochemical and geochemical processes integrated in their model framework, process-based biogeochemical models have been recognized as a powerful tool for understanding the complex transformations of $\mathrm{N}$ in terrestrial ecosystems. However, most extant biogeochemical models are unable to account for the transport of nutrients through lateral flow because of the lack of relevant hydrologic processes. This deficiency limits the application of biogeochemical models in simulations of $\mathrm{N}$ loading at the watershed scale. To meet the challenge, it is necessary to enhance biogeochemical models by incorporating hydrologic features.

Can a biogeochemical model be enhanced to quantify $\mathrm{N}$ loading at a watershed scale by incorporating basic hydrologic features into the model framework? Based on the studies reported in this paper and a previous study (Deng et al., 2011), our answer is positive. In the early study, the DNDC was modified by including two hydrologic features in the model framework, and the new model was successfully tested for simulating the surface runoff flow, subsurface drainage flow, sediment yield, and $\mathrm{N}$ loading from a typical dry land field (15.0 ha, accounted for approximately $78 \%$ of the total crop fields) within the Yanting watershed (Deng et al., 2011). The study has set a sound basis for the model to be applied for simulating $\mathrm{N}$ loading from the entire watershed. In this study, we further tested the model at the watershed scale through integrating the model with the GIS input database. The DNDC model possesses relatively detailed and thoroughly tested algorithms simulating transformations of soil N. The model is therefore able to provide reliable estimates of $\mathrm{N}$ losses across a wide range of climatic, soil, and 
Table 2. The modeled average and total $\mathrm{N}$ loss rates for different land use types in 2008.

\begin{tabular}{|c|c|c|c|c|c|c|c|c|c|c|c|c|}
\hline \multirow[t]{2}{*}{ Land types } & \multirow{2}{*}{$\begin{array}{l}\text { Area } \\
\text { (ha) }\end{array}$} & \multirow[t]{2}{*}{ FR } & \multicolumn{5}{|c|}{ Average $\mathrm{N}$ loss rate $\left(\mathrm{kg} \mathrm{Nha}^{-1} \mathrm{yr}^{-1}\right)$} & \multicolumn{5}{|c|}{ Total $\mathrm{N}$ loss in the watershed $\left(\mathrm{kg} \mathrm{N} \mathrm{yr}^{-1}\right)$} \\
\hline & & & $\mathrm{TN}$ & $\mathrm{NH}_{3}$ & $\mathrm{~N}_{2} \mathrm{O}$ & NO & $\mathrm{N}_{2}$ & $\mathrm{TN}$ & $\mathrm{NH}_{3}$ & $\mathrm{~N}_{2} \mathrm{O}$ & $\mathrm{NO}$ & $\mathrm{N}_{2}$ \\
\hline Dry land & 15 & 329 & 35 & 78 & 1.8 & 0.3 & 0.5 & 525 & 1170 & 27 & 4.5 & 7.5 \\
\hline Seasonal paddy & 2.5 & 283 & 19 & 37 & 1.8 & 0.3 & 11.8 & 48 & 93 & 4.5 & 0.8 & 29.5 \\
\hline Paddy field & 1.8 & 130 & 17 & 19 & 0.1 & 0.1 & 3.3 & 31 & 34 & 0.2 & 0.2 & 5.9 \\
\hline Grassplot & 1.1 & 0 & 5 & 1.8 & 0.2 & 0.1 & 0.2 & 5 & 2.0 & 0.2 & 0.1 & 0.2 \\
\hline Forest land & 11 & 0 & 11 & 0 & 0.2 & 0 & 0.8 & 121 & 0 & 2.2 & 0 & 8.8 \\
\hline Residential region $^{\mathrm{a}}$ & 3.7 & 0 & 47 & & & & & 174 & & & & \\
\hline Sum & 35.1 & & & & & & & 904 & 1299 & 34.1 & 5.6 & 51.9 \\
\hline
\end{tabular}

$\mathrm{TN}$, Total nitrogen transported with runoff (the sum of surface runoff and subsurface drainage flow).

FR, Fertilizer application rate, $\mathrm{kg} \mathrm{N} \mathrm{ha}^{-1} \mathrm{yr}^{-1}$.

${ }^{a} \mathrm{~N}$ drainage rates for the residential region were based on observations.

management conditions (Li et al., 2006; Giltrap et al., 2010). In view of the complexity and extreme variability of $\mathrm{N}$ dynamics, the comprehensive $\mathrm{N}$ transformation capacity represents an attractive feature for simulating $\mathrm{N}$ loading at the watershed scale. The new version of the DNDC includes this capability. Because the new added hydrological features help to integrate the water and N processes in DNDC, they should also improve DNDC's predictions on $\mathrm{N}$ gases fluxes. Implementation of the two hydrological functions embedded in the enhanced DNDC requires additional input information, particularly information on the topographic features that characterize the land surface. As reported in this paper, we used the DEM data with universal GIS software (ArcGIS, ESRI, USA) to generate the topographic features required to run the SCS curve and MUSLE functions at the watershed scale. However, several soil hydrologic parameters, such as the initial CN, K, C, and P, were empirically fixed in this study by calibration against field data. This approach could have produced uncertainties in the modeled results. To quantify the potential uncertainty derived from the calibration processes, we performed uncertainty analysis on selected agricultural fields (uplands with summer maize-winter wheat rotation) within the watershed using Monte Carlo method (Deng et al., 2011). This analysis showed that variance in the input parameters could introduce high potential uncertainties. However, the modeled results fell within the range of variation reported from the Monte Carlo simulations and were comparable with the means obtained across all simulations (Deng et al., 2011). In general, our study indicated that processoriented biogeochemical models, such as DNDC, could contribute to $\mathrm{N}$ loading studies if enhancements relating to hydrology were included in the models. The enhancements of DNDC should provide new opportunities to estimate $\mathrm{N}$ loading and to assess agroecosystem management at a watershed scale.

During the simulation of $\mathrm{N}$ loading, DNDC automatically calculated emissions of nitrogenous gases $\left(\mathrm{NH}_{3}, \mathrm{~N}_{2} \mathrm{O}, \mathrm{NO}\right.$, and $\mathrm{N}_{2}$ ) across different land use types within the watershed. The simulated $\mathrm{NH}_{3}$ volatilization fluxes showed as one of the major $\mathrm{N}$ losses from the croplands, ranging from $19 \mathrm{~kg} \mathrm{Nha}^{-1} \mathrm{yr}^{-1}$ in the paddy field to $78 \mathrm{~kg} \mathrm{~N} \mathrm{ha}^{-1} \mathrm{yr}^{-1}$ in the dry land. The modeled high $\mathrm{NH}_{3}$ volatilization rates were related to the high application rates of ammonium bicarbonate and urea (130-330 $\mathrm{kg} \mathrm{Nha}^{-1} \mathrm{yr}^{-1}$ ) as well as the high soil $\mathrm{pH}$ (about 8.3). The modeled results demonstrated high diversity of nitrification or denitrification rates across the land use types. In the dry land, low soil moisture restricted denitrification; as a result, DNDC predicted low $\mathrm{N}_{2}$ emission rate $\left(0.5 \mathrm{~kg} \mathrm{Nha}^{-1} \mathrm{yr}^{-1}\right)$ and the simulated $\mathrm{N}_{2} \mathrm{O}$ and $\mathrm{NO}$ emissions were mainly produced through nitrification. The modeled denitrification rate was relatively higher in the seasonal paddy and paddy field under flooded condition. Especially in the seasonal paddy, DNDC simulated the accumulation of nitrate in the soil profile during the cultivation of upland crop and a significant portion of the accumulated nitrate was then denitrified into $\mathrm{N}_{2}$ (approximately $11.8 \mathrm{~kg} \mathrm{Nha}^{-1} \mathrm{yr}^{-1}$ ) during the continuing flooded season. For the paddy field with continuous flooding, DNDC predicted low $\mathrm{N}_{2} \mathrm{O}$ and $\mathrm{NO}$ emissions mainly due to the restricted nitrification. For grassplot and forest land, both nitrification and denitrification were restricted by the availability of soil N; therefore, DNDC simulated low emissions of $\mathrm{N}$-gases. However, it may be noteworthy that the modeled emissions of N-containing gases for the target watershed remain large uncertain because of the limited observations for model validation. Further tests are needed to verify the model capacity of quantifying nitrogenous gas emissions.

Modeling $\mathrm{N}$ transport and transformation at a watershed scale is in a very early stage. The process of applying the model to the Yanting watershed taught us that much additional work would be required to build a relatively comprehensive watershed model. For example, aquatic biogeochemistry dominates the channel processes. Our ignorance of these processes could produce significant uncertainty in 
the simulation of $\mathrm{N}$ loading from the watershed. When the various $\mathrm{N}$ species carried by the runoff or sediment enter the channel or stream systems, a series of complex processes will occur in the aquatic environment. These processes could include sediment deposition, uptake by aquatic plants, retention of nutrients, microorganism-mediated transformations (e.g., decomposition, mineralization, nitrification, and denitrification), and substrate exchange at the sediment-water interface (Alexander et al., 2000; Rabalais, 2002; Seitzinger et al., 2002; Vymazal, 2007). Most of these processes cause the removal of $\mathrm{N}$ during its transport through channel or stream systems and thereby reduce the $\mathrm{N}$ loading rate at the outlet of the watershed. As a terrestrial model, the DNDC does not incorporate aquatic biogeochemistry. In this study, empirical reduction efficiency indices were adopted, based on local observations, to estimate the losses of sediment or $\mathrm{N}$ during the transport through the channels. The modeled results using this simplification appeared acceptable for this small watershed. However, a model incorporating this simplification may not be applicable to large watersheds, in which the $\mathrm{N}$ biogeochemical processes occurring in water bodies would play an important role in altering the concentration or chemical status of $\mathrm{N}$. To improve the applicability of the DNDC to modeling $\mathrm{N}$ loading at a watershed scale, we plan to gradually develop the capability to incorporate representations of the aquatic biogeochemical processes in the overall model framework.

Acknowledgements. This study was supported by the National Program on Key Basic Research Project of China (2012CB417106, 2012CB417101), the National Natural Science Foundation of China (41021004), and the European Union (NitroEurope IP 017841).

Edited by: G. Billen

\section{References}

Alexander, R. B., Smith, R. A., and Schwarz, G. E.: Effect of stream channel size on the delivery of nitrogen to the Gulf of Mexico, Nature, 403, 758-761, 2000.

Arnold, J. G., Srinivasan, R., Muttiah, R. S., and Williams, J. R.: Large area hydrologic modeling and assessment part I: model development 1, J. Am. Water Resour. As., 34, 73-89, 1998.

Band, L. E., Tague C. L., Groffman P., and Belt, K.: Forest ecosystem processes at the watershed scale: hydrologic and ecological controls of nitrogen export, Hydrol. Process., 15, 2013-2028, 2001.

Bicknell, B. R., Imhoff, J. C., Kittle, J. L., Donigian, A. S., and Johanson, R. C.: Hydrologic simulation program - FORTRAN user's manual for release 11, Environmental Protection Agency of United States, Georgia, USA, 1997.

Boyer, E. W., Alexander, R. B., Parton, W. J., Li, C., ButterbachBahl, K., Donner, S. D., Skaggs, R. W., and Delgrosso S. J.: Modeling denitrification in terrestrial and aquatic ecosystems at regional scales, Ecol. Appl., 16, 2123-2142, 2006.
Cai, C., Ding, S., Shi, Z., Huang, L., and Zhang, G.: Study of applying USLE and geographical information system IDRISI to predict soil erosion in small watershed, J. Soil Water Conserv., 14, 19-24, 2000.

Carpenter, S. R., Caraco, N. F., Correll, D. L., Howarth, R. W., Sharpley, A. N., and Smith, V. H.: Nonpoint pollution of surface waters with phosphors and nitrogen, Ecol. Appl., 8, 559-568, 1998.

Cassman, K. G., Dobermann, A., and Walters, D. T.: Agroecosystems, nitrogen-use efficiency, and nitrogen management, AMBIO, 31, 132-140, 2002.

Cirmo, C. P. and McDonnell, J. J.: Linking the hydrologic and biogeochemical controls of nitrogen transport in near-stream zones of temperate-forested catchments: a review, J. hydrol., 199, 88120, 1997.

Deng, J., Zhu, B., Zhou, Z., Zheng, X., Li, C., Wang, T., and Tang, J.: Modeling nitrogen loadings from agricultural soils in Southwest China with modified DNDC, J. Geophys. Res.-Biogeo., 116, G02020, doi:10.1029/2010JG001609, 2011.

Galloway, J. N., Aber, J. D., Erisman, J. W., Seitzinger, S. P., Howarth, R. H., Cowling, E. B., and Cosby, B. J.: The nitrogen cascade, BioScience, 53, 341-356, 2003.

Gile, J.: Nitrogen study fertilizes fears of pollution, Nature, 433, 791, 2005.

Giltrap, D. L., Li, C., and Saggar, S.: DNDC: a process-based model of greenhouse gas fluxes from agricultural soils, Agr. Ecosyst. Environ., 136, 292-300, 2010.

Gong, Z. T.: Chinese Soil Taxonomy, Science Press, Beijing, China, 160-166, 1999.

Haycock, N. E., Pinay, G., and Walker, C.: Nitrogen retention in river corridors: European perspective, AMBIO, 22, 340-346, 1993.

Hu, X., McIsaac, G. F., David, M. B., and Louwers, C. A. L.: Modeling riverine nitrate export from an East-Central Illinois watershed using SWAT, J. Environ. Qual., 36, 996-1005, 2007.

Hua, L., He, X., and Zhu, B.: Soil erosion distribution of a small watershed in the hilly area of central Sichuan basin, B. Soil Water Conserv., 27, 111-115, 2007.

IPCC: Climate change 2007: the physical science basis; Contribution of Working Group I to the fourth Assessment Report of the Intergovernmental Panel on Climate Change, Cambridge University Press, Cambridge, United Kingdom and New York, NY, USA, 2007.

Jaynes, D. B., Colvin, T. S., Karlen, D. L., Cambardella, C. A., and Meek, D. W.: Nitrate loss in subsurface drainage as affected by nitrogen fertilizer rate, J. Environ. Qual., 30, 1305-1314, 2001.

Jenson, S. K. and Domingue, J. O.: Extracting topographic structure from digital elevation data for geographic information system analysis, Photogramm. Eng. Rem. S., 54, 1593-1600, 1988.

Johnsson, H., Bergstrom, L., Jansson, P. E., and Paustian, K.: Simulated nitrogen dynamics and losses in a layered agricultural soil, Agr. Ecosyst. Environ., 18, 333-356, 1987.

Jordan, T. E., Correll, D. L., and Weller, D. E.: Effects of agriculture on discharges of nutrients from coastal plain watersheds of Chesapeake Bay, J. Environ. Qual., 26, 836-848, 1997a.

Jordan, T. E., Correll, D. L., and Weller, D. E.: Relating nutrient discharges from watersheds to land use and streamflow variability, Water Resour. Res., 33, 2579-2590, 1997 b.

Kimura, S. D., Hatano, R., and Okazaki, M.: Characteristics and 
issues related to regional-scale modeling of nitrogen flows, Soil Sci. Plant Nutr., 55, 1-12, 2009.

Kramer, S., Reganold, J., Glover, J., Bohannan, B., and Mooney, H.: Reduced nitrate leaching and enhanced denitrifier activity and efficiency in organically fertilized soils, PNAS, 103, 45224527, 2006.

Leavesley, G. H., Markstrom, S. L., Restrepo, P. J., and Viger, R. J.: A modular approach to addressing model design, scale, and parameter estimation issues in distributed hydrological modeling, Hydrol. Process., 16, 173-187, 2002.

Li, C.: Modeling trace gas emissions from agricultural ecosystems, Nutr. Cycl. Agroecosyst., 58, 259-276, 2000.

Li, C., Frolking, S., and Frolking, T. A.: A model of nitrous oxide evolution from soil driven by rainfall events: 1 . Model structure and sensitivity, J. Geophys. Res.-Atmos., 97, 9759-9776, 1992a.

Li, C., Frolking, S., and Frolking, T. A.: A model of nitrous oxide evolution from soil driven by rainfall events: 2 . Model applications, J. Geophys. Res.-Atmos., 97, 9777-9783, 1992b.

Li, C., Aber, J., Stange, F., Butterbach-Bahl, K., and Papen, H.: A process-oriented model of $\mathrm{N}_{2} \mathrm{O}$ and $\mathrm{NO}$ emissions from forest soils: 1. Model development, J. Geophys. Res.-Atmos., 105, 4365-4384, 2000.

Li, C., Farahbakhshazad, N., Jaynes, D. B., Dinnes, D. L., Salas, W., and McLaughin, D.: Modeling nitrate leaching with a biogeochemical model modified based on observations in a row-crop field in Iowa, Ecol. Model., 196, 116-130, doi:10.1016/j.ecomodel.2006.02.007, 2006.

Luo, Z. X.: Stormwater runoff pollution and its control mechanism of natural ditch in a rural township - A case study of Linshan rural township in the hilly area of purple soils, China, Ph. D. thesis, Chinese Academy of Sciences, China, 2008.

Luo, Z. X., Zhu, B., Tang, J., Wang, T., Zhang, J., and Wang, Z.: Primary mechanisms of nitrogen and phosphorus removal from stormwater runoff by a natural ditch in a rural township, China Environmental Science, 29, 561-568, 2009.

Maidment, D. R.: Arc Hydro: GIS for water resources, Esri Press, USA, 2002.

Martz, L. W. and Garbrecht, J.: Automated extraction of drainage network and watershed data from digital elevation models, Water Resour. Bull., 29, 901-908, 1993.

Miehle, P., Liversley, S. J., Li, C., Feikema, P. M., Adams, M. A., and Arndt, S. K.: Quantifying uncertainty from large-scale model predictions of forest carbon dynamics, Global Change Biol., 12, 1421-1434, doi:10.1111/j.1365-2486.2006.01176.x, 2006.

Mockus, V.: Hydrology, in: National Engineering Handbook, Section 4, United States Department of Agriculture, Washington, DC, 1972.

Moffat, A. S.: Ecology: Global nitrogen overload problem grows critical, Science, 279, 988, 1998.

Nash, J. E. and Sutcliffe, J. V.: River flow forecasting through conceptual models part I: A discussion of principles, J. hydrol., 10, 282-290, 1970.

Neitsch, S. L., Arnold, J. G., Kiniry, J. R., Williams, J. R., and King, K. W.: Soil and water assessment tool theoretical documentation, Blackland Research Center, Texas Agricultural Experiment Station, Temple, Texas, 2001.

Rabalais, N. N.: Nitrogen in aquatic ecosystems, AMBIO, 31, 102$112,2002$.
Rabalais, N. N., Turner, R. E., Justic, D., Dortch, Q., Wiseman, Jr. W., and Gupta, B. K. S.: Nutrient changes in the Mississippi river and system responses on the adjacent continental shelf, Estuaries, 19, 386-407, 1996.

Refsgaard, J. C. and Storm, B.: Mike She, in: Computer Models of Watershed Hydrology, Water Resources Publications, Colorado, USA, 1995.

Saleh, A., Arnold, J. G., Gassman, P. W., Hauck, L. M., Rosenthal, W. D., Williams, J. R., and McFarland, A. M. S.: Application of SWAT for the upper North Bosque River watershed, T. ASAE, 43, 1077-1087, 2000.

Schlesinger, W. H., Abrahams, A. D., Parsons, A. J., and Wainwright, J.: Nutrient losses in runoff from grassland and shrubland habitats in Southern New Mexico: I. Rainfall simulation experiments, Biogeochemistry, 45, 21-34, 1999.

Seitzinger, S.: Nitrogen cycle - Out of reach, Nature, 452, 162-163, 2008.

Seitzinger, S. P., Styles, R. V., Boyer, E. W., Alexander, R. B., Billen, G., Howarth, R. W., Mayer, B., and Breemen, N.: Nitrogen retention in rivers: model development and application to watersheds in the northeastern USA, Biogeochemistry, 57, 199237, 2002.

Seitzinger, S., Harrison, J. A., Dumont, E., Beusen, A. H. W., and Bowman, A. F.: Source and delivery of carbon, nitrogen and phosphorous to the coastal zone: An overview of Global Nutrient Export from Watershed (NEWS) models and their application, Global Biogeochem. Cy., 19, GB4S01, doi:10.1029/2005GB002606, 2005.

Smith, R. A., Schwarz, G. E., and Alexander, R. B.: Regional interpretation of water-quality monitoring data, Water Resour. Res., 33, 2781-2798, 1997.

Stange, F., Butterbach-Bahl, K., Papen, H., Zechmeister-Boltenster, S., Li, C., and Aber, J.: A process-oriented model of $\mathrm{N}_{2} \mathrm{O}$ and NO emissions from forest soils: 2 . Sensitivity analysis and validation, J. Geophys. Res.-Atmos., 105, 4385-4398, 2000.

Tague, C. L. and Band, L. E.: RHESSys: Regional Hydro-ecologic Simulation System - an object-oriented approach to spatially distributed modeling of carbon, water, and nutrient cycling, Earth Interact., 8, 1-40, 2004.

Tonitto, C., David, M. B., Drinkwater, L. E., and Li, C.: Application of the DNDC model to tile-drained Illinois agroecosystems: model calibration, validation, and uncertainty analysis, Nutr. Cycl. Agroecosyst., 78, 51-63, 2007.

Tonitto, C., Li, C., Seidel, R., and Drinkwater, L. E.: Application of the DNDC model to the Rodale Institute Farming Systems Trial: Challenges for the validation of drainage and nitrate leaching in agroecosystem models, Nutr. Cycl. Agroecosyst., 87, 483-494, doi:10.1007/s10705-010-9354-8, 2010.

Turcotte, R., Fortin, J. P., Rousseau, A. N., Massicotte, S., and Villeneuve, J. P.: Determination of the drainage structure of a watershed using a digital elevation model and a digital river and lake network, J. Hydrol., 240, 225-242, 2001.

Vitousek, P. M., Aber, J. D., Howarth, R. W., Likens, G. E., Matson, P. A., Schindler, D. W., Schlesinger, W. H., and Tilman, D. G.: Human alteration of the global nitrogen cycle: sources and consequences, Ecol. Appl., 7, 737-750, 1997.

Vymazal, J.: Removal of nutrients in various types of constructed wetlands, Sci. Total Environ., 380, 28-45. 2007.

Wang, T., Zhu, B., Gao, M. R., Xu, T. P., and Kuang, F. H.: Ni- 
trate pollution of groundwater in a typical small watershed in the central Sichuan hilly region, J. Ecol. Rural Environ., 22, 84-87, 2006.

Wang, X. G., Zhu, B., Gao, M., Wang, Y., and Duan, W.: Measurement and simulation of $\mathrm{N}_{2} \mathrm{O}$ emissions from an alder and cypress mixed plantation in hilly areas of the central Sichuan Basin, China Environmental Science, 29, 242-247, 2009.

Whiteaker, T., Schneider, K., and Maidment, D.: Applying the ArcGIS Hydro Data Model, University of Texas at Austin, Texas, 2003.

Williams, J. R.: Sediment-yield prediction with universal equation using runoff energy factor, in: Present and prospective technology for predicting sediment yields and sources, United States Department of Agriculture, USA, 244-252, 1975.

Williams, J. R.: The EPIC model, in: Computer models of watershed hydrology, Water Resources Publications, Colorado, USA, 909-1000, 1995.

Wischmeier, W. H. and Smith, D. D.: Predicting rainfall erosion losses: a guide to conservation planning, United States Department of Agriculture, Washington, DC, 1978.
World Health Organization: Guidelines for drinking water quality, WHO, Geneva, Switzerland, 2004.

Yuan, Y. P., Bingner, B. L., and Rebich, R. A.: Evaluation of AnnAGNPS nitrogen loading in an agricultural watershed, J. AM. WATER RESOUR. AS., 39, 457-466, 2003.

Zhang, Y., Li, C., Trettin, C. C., Li, H., and Sun, G.: An integrated model of soil, hydrology and vegetation for carbon dynamics in wetland ecosystems, Global Biogeochem. Cy., 16, 1061, 17 pp., doi:10.1029/2001GB001838, 2002.

Zhu, B., Peng, K., and Xie, H. M.: Nitrogen balance of agroecosystem in a typical watershed in the hilly area of central Sichuan Basin, CJEA., 14, 108-111, 2006.

Zhu, B., Wang, T., Kuang, F. H., Luo, Z. X., Tang, J. L., and Xu, T. P.: Measurements of nitrate leaching from a hillslope cropland in the Central Sichuan Basin, China, Soil Sci. Soc. Am. J., 73, 1419-1426, 2009.

Zhu, Z., Noese, D., and Sun, B.: Policy for reducing non-point pollution from crop production in China, China Environmental Science Press, Beijing, China, 2006. 